This is the accepted version of the article published by Sage in Critical Sociology Vol. 43 (4-5), 611-613.

Published version available from: https://doi.org/10.1177/0896920517699153

Accepted version downloaded from SOAS Research Online: http://eprints.soas.ac.uk/24428/

\title{
Introduction: Neoliberalism Since the Crisis
}

\author{
Damien Cahill, University of Sydney
}

Alfredo Saad-Filho, SOAS University of London

Among critical social scientists and progressive activists alike, analysis of neoliberalism has become inseparablefrom the examination of the crisis that has engulfed the global economy since 2007. When the crisis began it was interpreted by many, not least the mainstream media and even some of the staunchest advocates of neoliberalism, as a crisis of the model of capitalism that had dominated global economic policy for the previous two-and-a-half-decades. Moreover, neoliberal policies promoting financialization were widely held to be responsible for the onset of crisis. As states responded to the crisis with (what appeared to be) new restrictions on finance capital and the nationalisation of the some of the world's largest banks and financial corporations, many thought it reasonable to conclude that the neoliberal era was coming to an end.

Yet, as the global economic crisis continues, so does the rollout of recognizably neoliberal policies of 'austerity', privatization, deregulation and the rollback of more and more features of the welfare states built in the postwar era. They have been used as tools of crisis management, even as states have experimented with new forms of economic regulation, such as quantitative easing. Particularly in those countries worst hit by recession, such tools have deepened and (provisionally) channelled abroad the economic crisis, instead of resolving it, while contributing to the stagnation of demand and miring ordinary people in perpetual austerity.

It is perhaps unsurprising then that contestation over post-crisis neoliberalism is evident in many of the recent seismic political developments across the globe. Most obviously, the rise of radical left-wing parties in Greece, Spain, Portugal and elsewhere, and the popularity of leaders such as British Labour's Jeremy Corbyn, or Bernie Sanders in the USA, are direct reactions to the devastating effects of enforced neoliberal austerity. These follow earlier political movements against some of the harshest forms of neoliberalism in the global South - such as the socalled 'Pink Tide' that carried a series of (more or less radical) left-wing parties to government across Latin America. But the echoes of dissent against neoliberalism, however distorted, can also be heard in the successful 'leave' campaign in the British referendum on its EU membership, in some of Donald Trump's economic policies (even as he is so obviously one of the world's leading beneficiaries of neoliberal policies), in the rise of the National Front, in France, alongside the mobilisation of racial prejudices and national imaginaries in many countries.

The premise of this special issue of Critical Sociology is that an understanding of neoliberalism since the crisis is crucial for comprehending the contradictions, conflicts and social forces reshaping the contemporary global political economy. 
This is the accepted version of the article published by Sage in Critical Sociology Vol. 43 (4-5), 611-613. Published version available from: https://doi.org/10.1177/0896920517699153

Accepted version downloaded from SOAS Research Online: http://eprints.soas.ac.uk/24428/

Despite scholarship on, about and around neoliberalism having burgeoned since the onset of the global crisis, a settled definition of neoliberalism remains elusive. This special issue takes the current crisis as a vantage point to shed new light on the central dynamics of neoliberalism and to reflect critically upon the established modes by which it is theorized. This entails an appreciation of the distinctiveness of neoliberalism and its dynamics, as well as the ways in which it has been reshaped by, and is in turn reshaping, the ongoing crisis and peoples' variegated experiences of everyday life. While neoliberalism has defied those who predicted that the crisis would lead to its demise, the question remains as to whether this marks a new era of reconfigured neoliberalisation, whether new modalities of capitalist regulation will emerge, or if we can only look forward to more of the same with, possibly, continuing financial instability.

Each of the articles in this special issue offers unique a perspective on neoliberalism since the crisis. In 'Crisis Neoliberalism and Regimes of Permanent Exception', Neil Davidson challenges the notion that the current crisis marks the end of neoliberalism and the beginning of a new stage of capitalist development. Rather, Davidson argues that the very success of neoliberalism in transforming states in the interests of capital, hollowing out politics and weakening organized labour, has effectively locked governments into imposing further rounds of neoliberalisation. Even though this strategy may be supported by sections of capital, it is unlikely to secure a resolution to the systemic crisis of neoliberal capitalism.

As the global economic crisis has unfolded the EU has become one of the central sites of contestation over neoliberalism. In 'Transnational Class Formations, European Crisis and the Silent Revolution', Stephen Gill examines the ways in which neoliberal forms of governance have become institutionalized within and through the EU, effectively binding states to further neoliberalisation and austerity. Whilst the ruling classes whom this benefits are in the ascendancy and face relatively fragmented subaltern classes, the EU is nonetheless beset by deepening economic and social contradictions generated by this disciplinary neoliberalism. Although not discussed in this article because it was written prior to its occurrence, the 'Brexit' vote is consistent with the approach in this article.

Attention then turns to how neoliberal processes of financialisation have been experienced by indebted households. In 'Exposing the limits of financialised debt crisis: the household economy and the everyday care of debts', Johnna Montgomerie and Daniela Tepe-Belfrage examine how financialised debt becomes imbricated within the caring relationships of the household and its inter-personal emotional and legal ties. The breakdown of the social reproduction of household debt, they suggest, was at the heart of the subprime crisis, which triggered the global financial contagion. Thus the conditions under which finacialised debt is reproduced through the household are crucial for an understanding of the (in)ability of neoliberalism to be sustained over time.

Yet, in seeking to understand neoliberalism it is also important to look beyond the current crisis and investigate factors leading to the emergence of new forms 
This is the accepted version of the article published by Sage in Critical Sociology Vol. 43 (4-5), 611-613.

Published version available from: https://doi.org/10.1177/0896920517699153

Accepted version downloaded from SOAS Research Online: http://eprints.soas.ac.uk/24428/

of regulation from the 1970s onwards. In 'How Labour Made Neoliberalism', Elizabeth Humphrys and Damien Cahill use the crisis as an opportunity to destabilize the dominant progressive narrative of the origins of neoliberalism: that it was implemented in its vanguard phase exclusively by parties of the centre-right, and imposed coercively upon labour movements. They take Australia as a case study, in which the period of most radical neoliberalisation (1983-1996) was also a period of uninterrupted Labor Party governance. Due to formal agreements during this period between the Labor government and the trade union leadership, Humphrys and Cahill argue that in Australia, neoliberalism was, effectively, co-authored by labour, which effectively disorganized itself through the neoliberalisation of the state and economy. This experience should prompt a re-evaluation of how scholars understand the role of labour movements and labour parties in the roll-out of neoliberalism more generally.

Finally, in 'Thirteen Things You Need To Know About Neoliberlaism', Ben Fine and Alfredo Saad-Filho argue that neoliberalism is most usefully understood as the mode of existence of contemporary capitalism. Among the central features of neoliberalism, they contend, is financialisation, which conditions both economic and social reproduction, and distinguishes the neoliberal form of capitalism from earlier forms such as Fordism, marking it as more volatile and generating lower growth than its immediate predecessor. With financialisation at its heart, neoliberalism challenges existing regimes of social protection, even as it underpins new forms of privatized social provisioning. While neoliberalism has constrained the scope for progressive economic transformation, the current crisis offers a context in which new challenges for neoliberalism might plausibly be predicted to emerge. 